\title{
An Assessment of Lodgers' Value Perception of Hotel Facilities and Services
}

\author{
Austin c. Otegbulu PhD \& Odu Tenigbade MSc \\ Department of Estate Management \\ University of Lagos, Nigeria \\ E-mail: austinotegbulu@yahoo.com,'tenigbade@yahoo.co.uk
}

Received: March 4, 2011

Accepted: July 4, 2011

doi:10.5539/jsd.v4n4p91

\begin{abstract}
This paper aims at investigating attributes that affect hotel room pricing based on customers' perception. A related objective is to create a model of these perceptions which will serve as a framework for would-be investors and managers. The paper also examines previous literature on the issue of lodgers' perception of hotel attributes and pricing techniques. A hedonic model was developed which included the identified significant attributes. The findings show that regular power and water supply, closeness to the city centre and good room service are some of the attributes that lodgers find most important in a hotel accommodation.
\end{abstract}

Keywords: Hotels, Hotel attributes, Hedonic Pricing, Ikeja

\section{Introduction}

According to Scott (2008) the term hotel encompasses a wide spectrum of property types from larger units having up to or may be in excess of 1000 letting bedrooms, to smaller units maybe having as few as 10 or even less. They range from modern purpose built properties incorporating the latest design techniques to converted manor houses or boarding inns. Services provided vary considerably between hotel types.

Pearce (1995) suggests that hotels are "the most visible and pure manifestation of tourism in the city." The continued springing up of hotels and guest houses across Nigeria gives evidence not only to the fact that the tourism industry is growing but also that the business is continually being perceived as a profitable one. However, it is expedient that every rational investor ascertains the viability of an investment before committing funds it. In order to ensure that their investment is profitable, property owners require appraisers to forecast the performance of such investments. The viability of an investment in hotels can only be ascertained when the appropriate attributes in line with customer tastes and preferences are properly evaluated through market research. To achieve economic sustainability in hotel development, however, it is expedient that every rational investor ascertains the viability of an investment before committing funds it. Investors must identify those attributes that attract customers and arrange them in hierarchal order or scale of preferences. This will guide them in making investment decisions in a cost effective manner. Poor pre investment planning studies and its consequent poor financial returns undermines the sustainability of projects. Paying detailed attention on the significant attributes will enhance the value of hotel investments.

In valuing hotels, one of the commonest methods used is the income capitalisation method as most hotel investors give weight to it (De-Roos and Rushmore, 2006). The income capitalization approach is based on the principle that the value of an investment is a product of its net returns. The market value of income-producing properties, such as hotels can be determined by capitalizing the net income estimated by a forecast of income and expense along with the anticipated proceeds from a future sale. The foregoing shows that the income of the investment may be the most important factor to the investor.

The quality of income achieved by the investment is also a function of the availability and pricing of services available in the facility. This brings us to the question of why hotel room rates (some times in the same location) vary from each other; another question is why despite the price difference, some lodgers would choose to lodge in a hotel with higher room rates. These go to show that certain attributes attract lodgers to particular accommodations. There has however been little or no study to establish a pattern of lodgers' willingness to pay for attributes or facilities available to them in hotels.

This study seeks to investigate how hotel and guest house lodgers perceive lodging attributes in relation to the rates they pay for the rooms. The objectives to achieve this are:

- To identify the attributes that lodgers consider most important to them in a hotel/ guest house

- To assess the relative importance of each attribute and the price-value relationship

- $\quad$ To come up with a model that expresses the price-value relationship

Literature

Hotels provide facilities for the transaction of meetings and conferences, and for recreation and entertainment. 
According to Middleton and Clarke (1999), accommodation plays a functional role by providing the facilities that make travel convenient and comfortable. In a conceptual model of tourism market system, Hall (1995) regarded accommodation as one of the more critical components on the demand side-because accommodation has a major influence on the type of visitors who come to a destination. Cooper, Fletcher, Gilbert and Wan hill (1996) suggested that accommodation provides an essential support service to satisfy the wider motivation that brought the visitor to the destination. Hotels must therefore ensure that they provide the kind of services that will satisfy current customers and motivate new ones.

\section{Demand and Market Segmentation/Analysis}

Hotels commonly provide a number of different services within the same or different buildings which are often available for the use of both residents of the hotel and non-residents. These include the provision of letting bedroom, food and beverage services in restaurants, bars and banqueting rooms, conference/mailing rooms and leisure facilities. Also of importance are; the total super capacity; that is whether the rooms are ensuite bathrooms or showers, the heating or air-conditioning system; the quality, condition and standard of furnishing and fittings; and the facilities provided including such items as televisions, radio, fax machines, modern point internet services, in-house movies, direct-dial telephones, hair-dryers, mini-bars, safes, tea and coffee making facilities, pressing irons etc. (Scott 2008).

The above facilities/ services will appeal to different customers in varying mix. Depending on the class of hotels. What should be provided must be in response to customers' expectations and depends on market study, which is a management tool for decision making and is used as well for planning and investment analysis (Shilling 2002).

Market studies is an important part of any business plan. It can be useful in estimating future supply and demand, profiling customers and assessing competition to discover un-defected markets. These studies also allow for tailoring your product to the unique needs of a particular customer(s). The miracle of success in hotel development occurs when you can provide not only your target needs but exceeds their expectations (Kone 2006). When a real estate product is provided in response to user expectations, its productivity will be enhanced. The productivity of Real estate development is the ability to satisfy the need of its development.

Property productivity analysis and market segment analysis both identify the physical, locational, legal and design/amenity attribute of the subject property (Hotel). These qualities of the property account for its utility and productivity. The analysis will seek answers to the following questions.

* What demand is there for the attributes of the property investment (Hotel)? Who can use these attributes?

* How will the productivity attributes of the particular hotel property attract users to the investment or facility?

* How many people can afford to pay for the attributes of the particular facility?

* How much are people willing to pay for these attributes.

For a hotel investment by identifying the attributes, the appraiser has also defined the market segment in which the property will appeal (Fanning 2005).

In effect real estate market segmentation implies deviding market demand into meaningful user groups based on the property attributes.

Kivela (1996) viewed consumer products and services and bundle of attributes, or features, and benefit; and stated that these attributes that directly influence customers choice are termed 'determinants' attributes. These attributes which could be different from those 'competitors' are offering may be key factors in determining consumers intentions regarding purchases.

\section{Pricing Hotel Facilities and Services}

Pricing has been identified to be the singular element in the accommodation marketing mix that impacts directly on revenues (Chen and Rothschild, 2010). There have been various literatures on pricing in the hospitality industry. Shoemaker (2003) while reviewing the trend of pricing of services in the hospitality industry identified four phases of pricing in the hotel business viz:

- Rates varying by season

- Yield management system (revenue per available rooms)

- Revenue management based on available customers

- Value pricing (based on value received and not cost to produce)

He further opined that pricing will reach a phase when the consumer is completely incorporated in the pricing decision.

White (2000) identifies three historic methods of pricing room rates as the $\$ 1$ per $\$ 1000$ rule (charging one dollar per one thousand-dollars invested to include construction and equipment cost), the Hubbart Formula (covering all operating costs while providing a 15 percent profit on investment), and management decisions (hotel managers determined their prices relative to the competition). Lewis and Shoemaker (1997) postulated that a technique 
known as Price Sensitivity Measurement (PSM) can be used to determine how consumers' perception of value are affected by the interaction of price and quality. Price-value they said has become a common expression for a relationship that goes beyond the manifested monetary price of an item or service. 'In spite of the continued campaign for consumer participation in service pricing, Hinterhuber (2008) identified five main obstacles to the implementation of value-based pricing strategies: deficits in value assessment; deficits in value communication; lack of effective market segmentation; deficits in sales force management; and lack of support from senior management. This study tries to tackle the problems associated with deficits in value assessment.

More recent literature however tends more towards incorporating customers' value perceptions into the pricing of hotel accommodations. Varini et al. ( 2003) are of the opinion that though lodgers Wilingness-To-Pay (WTP) for attributes is not sufficient for profit optimisation, it is a first indicator.

Other researchers such as White (2000), Espinet et al (2001 and2003) and Chen and Rothschild (2010) have employed the Hedonic pricing methods to analyze the level of significance of certain hotel attributes as perceived by lodgers. It is important to point out that the attributes of hotels is what is subject to marketing and not the hotel as a single commodity.

\section{Hedonic Pricing in Hotels and Guest Houses}

Rosen (1974) defines hedonic pricing as "the implicit prices of attributes that are revealed to economic agents from observed prices of differentiated products and the specific amounts of characteristics associated with them." The hedonic price theory assumes that rather than a commodity being priced as a whole, the components or attributes that make up the commodity are priced individually thereby taking into consideration the level of significance of each of the attributes.

Hedonic pricing though regularly used in housing valuation, has hardly had any recognition in the lodging sector in Nigeria. Espinet et al (2001) used the hedonic pricing model and found out that in the Spanish continental Mediterranean coast, besides hotel category, region, distance to the beach, availability of parking place and room equipment have an effect on peak price and also on seasonality. A study in 2003 also revealed that a significant attributes that have effect on price are town, hotel size, distance to the beach and availability of parking place. (Espinet, Saez, Coenders, \& Fluvia, 2003)

White (2000), while studying hotels in Arizona showed that site and situation attributes are systematically reflected in hotel room rates. Chen et al.'s (2010) study showed that in Taipei, while hotel location, the availability of LED (Light Emitting Diode) TV and the presence of conference facilities have significant effects on both weekday and weekend room rates, Internet access and the presence of a fitness centre have significant effects on weekday rates only, while room size has a significant effect on weekend rates only.

\section{Methodology}

This study covers hotels and guest houses in Ikeja Local Government Area of Lagos State. Lagos state is referred to as the commercial nerve centre of Nigeria and the presence of abundance of water bodies and the Central Business District also makes it a prime choice for tourists and businessmen alike. The list of hotels available in Ikeja was obtained from Nigerian Tourism Development Corporation (NTDC). The corporation has the function of regulating the tourism industry and updating tourism information among other duties. The NTDC provided a list of 63 registered hotels in Ikeja local government area. The sample size for this study is 32 hotels which is about $50 \%$ of the total population. The hotels in the sample are of different categories ranging from luxury hotels to guest houses. The sample is drawn randomly from major areas in Ikeja, these are: Allen Avenue, Opebi Road, Mobolaji Bank-Anthony way, Obafemi Awolowo Way, Kudirat Abiola Way, Toyin Street, Ikeja GRA and Adeniyi Jones Avenue.

This study examined 22 different attributes. These attributes are shown in Table 1 below:

The analysis of the data was carried out with the use of a Hedonic price model in line with the views of Espinet et al (2003) and Chen and Rothschild (2010). The dependent variable is the room rate per night charged on the rooms in the hotels/guest houses. While the independent variables were regrouped into 4 components namely; basic, physical, environmental and complementary attributes.

Out of a total of 200 questionnaires that were administered 154 were returned. The returned responses represented $77 \%$ of the total questionnaires administered.

\section{Results}

\section{Figure 1: Distribution of the Respondents by Sex}

Figure 1 shows the frequency distribution of the respondents by sex. This figure show that ninety-eight $(63.6 \%)$ of the respondents are males while fifty-six $(36.4 \%)$ of the respondents are females. This infers that there are more male lodgers than females.

\section{Figure 2: Distributions of the Respondents by Age}

Figure 2 shows the frequency distribution of the respondents by age. This figure show that sixty-six $(39.0 \%)$ of the respondents are between the age of 31-40years, forty-four (28.6\%) of the respondents are between the age of 
41-50years, forty $(26.0 \%)$ of the respondents are between the age of 20-30years, eight (5.2\%) of the respondents are between the age of 51-60yrs while two (1.3\%) of the respondents are more than 61years of age. This Data shows that most lodgers fall within the active ages of between $20-50$ years. This may also account for the high demand for high-tech attribute in hotels.

\section{Figure 3: Distributions of the Respondents by Occupational Status}

Figure 3 shows the frequency distribution of the respondents by occupational status. This figure shows that forty-two $(28.6 \%)$ of the respondents are professionals, forty-two $(27.3 \%)$ of the respondents are business $\mathrm{men} /$ women, twenty-four (15.6\%) of the respondents are civil servant, twenty-four (15.6\%) of the respondents belong to other occupation which is outside the category, twelve $(7.8 \%)$ of the respondents are students, six $(3.9 \%)$ of the respondents are banker while two $(1.3 \%)$ of the respondents are clergyman. From this, it is seen that majority of the respondents are business men/women.

\section{Figure 4: Nationality of respondents}

Figure 4 shows the frequency distribution of the respondents by nationality. This figure shows that one hundred and thirty $(84.4 \%)$ of the respondents are Nigerian while twenty-four $(15.6 \%)$ of the respondents are non-Nigerian. This shows an approximate ratio of 5:1 for Nigerians to non-Nigerian.

\section{Table 2: Reasons Respondents Lodge in Hotels/Guest Houses}

Table 2 shows the respondents by reasons for lodging in hotels/guest houses. Eighty-eight $(57.1 \%)$ of the respondents lodge in hotels/guest houses for business, thirty-two $(20.8 \%)$ of the respondents lodge in hotels/guest houses for leisure, eighteen $(11.7 \%)$ of the respondents lodge in hotels/guest houses for tourism while sixteen (10.4\%) of the respondents lodge in hotels/guest houses for other reasons not mentioned. This infers that business and imperatively necessity is a major reason why the respondents lodge in hotels/guest houses.

\section{Table 3: Respondents' Frequency of use of hotels}

According to table 3 , it is seen that majority of the respondents lodge in hotels/guest house once a week.

\section{Table 4: frequency of stay in Hotel}

From table 4, it is seen that majority of the respondents lodge in the hotels/guest houses in which they were interviewed once a week on the average. Tables 3 and 4 infer that the respondents have a considerably good knowledge of the attributes of the hotels/guest houses. This makes their views reliable.

\section{Table 5: Rate per Night for Accommodation}

Table 5 shows that fifty (32.5\%) of the respondents pay between N1,000-N10,000 per night for accommodation, forty-four $(28.6 \%)$ of the respondents pay between N11,000-N20,000, thirty-two $(20.8 \%)$ of the respondents pay more than $\mathrm{N} 40,000$, twenty $(13.0 \%)$ of the respondents spend between $\mathrm{N} 21,000-\mathrm{N} 30,000$ while eight $(5.2 \%)$ of the respondents pay between N31,000-N40,000.

\section{Table 6: Ranking of the Facilities Available to Respondents Hotel/Guest House}

Table 6 shows the ranking of the facilities available in hotels/guest houses. Regular water was ranked first with a Relative Impact Index (RII) of 0.93, constant power supply was ranked second with RII of 0.91, closeness of location to the city centre was ranked third with RII of 0.90 , The high ranking of these three attributes may be attributed to the generally poor state of infrastructure in the country which makes people seek for alternative supply of the facilities. Good room service was ranked fourth with RII of 0.90 , closeness to airport was ranked fifth with RII of 0.89 , variety of satellite TV station was ranked sixth with RII of 0.87 , availability of ample parking space was ranked seventh with RII of 0.87 , large room space was ranked eighth with RII of 0.86 , physical appearance of the hotel/guest house was ranked ninth with RII of 0.84 , laundry service was ranked tenth with RII of 0.84 , serenity of the neighborhood was ranked eleventh with RII of 0.83 , availability of bar/café was ranked twelve with RII of 0.79, availability of LCD TV in the room was ranked thirteenth with RII of 0.79 , variety in cuisine was ranked fourteenth with RII of 0.78 , availability of internet services was ranked fifteenth with RII of 0.76 , availability of shuttle service was ranked sixteenth with RII of 0.75 , affiliation to a chain of hotels was ranked seventeenth with RII of 0.73 , availability of swimming pool was ranked eighteenth with RII of 0.71 , availability of fitness centre/gymnasium was ranked nineteenth with RII of 0.71 , availability of a business centre was ranked twentieth with RII of 0.71 , availability of conference facilities was ranked twenty first with RII of 0.69 while availability of a club was ranked twenty second and least with RII of 0.64 among the attributes available to the respondents in hotels/guest houses in the study area. The last six attributes' being ranked most insignificant may be attributed to the fact that if the services are unavailable in the hotel/ guesthouse, they may be sought elsewhere and are therefore not regarded as essential to the lodgers.

\section{Table 7: Eigen Values Establishing Significant Values}

Table 7 shows the eigen values of the attributes. The table shows 4 attributes with eigen values greater than 1 . This means that these four attributes namely, regular water supply, constant power supply, closeness to city 
centre and good room service are the four most significant factors that influence lodgers willingness to pay for accommodation in the study area.

\section{Table 8: Factor Analysis of attributes}

The factor analysis technique was used to derive a cluster of relationship. Table 8 above shows the result of the Factor Analysis. Various tests for the appropriateness of factor analysis were done. These preliminary tests indicated that seven success factors namely, availability of shuttle services, Hotel/guest house is affiliation to a chain of hotels, Availability of swimming pool, Availability of fitness centre/gymnasium, Availability of a business centre, Availability of conference facilities and availability of a club were attributes that had insignificant influence on the rate of accommodation in hotels/guest houses. From the Factor Analysis, the following components were identified: COMONENT 1- Basic attributes, COMPONENT 2- Physical attributes, COMPONENT 3- Environmental attributes, COM4-Complementary attributes

\section{Table 9 and Table 10: Construction of Model}

The R Square value in the Model Summary table shows the amount of variance in the dependent variable that can be explained by the independent variable.

The calculated $t$ value for available facilities in hotel/guest house of 13.817 was greater than critical $t$ of 1.96 . This is significance at $95 \%$ confidence interval. This implies that available facilities in the hotel/guest house contributed significantly to the rate per night for the accommodation.

The model is therefore shown below

$\mathrm{Y}=-5.140+0.497 \mathrm{com}_{1}+0.305 \mathrm{com}_{2}+0.259 \mathrm{com}_{3}+0.231 \mathrm{com}_{4}+0.65_{\mathrm{E}}$

Where $\quad \mathrm{Y}=$ Rate per night;

$\mathrm{COM}_{1}=$ Basic attributes

$\mathrm{COM}_{2}=$ Physical attributes

$\mathrm{COM}_{3}=$ Environmental attributes

$\mathrm{COM}_{4}=$ Complementary attributes, therefore,

Rate per Night for Accommodation $=-5.140+0.497$ Basic attributes +0.305 Physical attributes +0.259

Environmental attributes +0.231 Complementary attributes.

The Unstandardized Coefficients $\beta$ column, gives us the coefficients of the independent variables in the regression equation including all the predictor variables. The largest influence on the rate per accommodation is from basic attributes, (0.497), next is physical attributes (0.305), next is environmental attributes (0.259) and the next is complementary attributes $(0.231)$. T-test results shows that the beta value is significantly higher than zero. This enabled the researcher to see the predictors that are significant. $\mathrm{R}$ is $0.663, \mathrm{R}^{2}$ is $0.439\left(\mathrm{ADR}^{2}=0.42\right)$. This explains about $42 \%$ of the variables affecting room rate in hotels and guest houses in the study area.

The four components can further be broken down into the following equations:

Basic attributes $=\mathrm{X}_{1}+\mathrm{X}_{2}+\mathrm{X}_{3}+\mathrm{X}_{4}+\mathrm{X}_{5}+\mathrm{X}_{6}+\mathrm{X}_{7}$

Where:

$\mathrm{X}_{1}=$ Regular water supply

$\mathrm{X}_{2}=$ Constant power supply

$\mathrm{X}_{3}=$ Location is close to the city centre

$\mathrm{X}_{4}=$ Good room service

$\mathrm{X}_{5}=$ Location is close to the airport

$\mathrm{X}_{6}=$ Variety of satellite TV stations

$\mathrm{X}_{7}=$ Availability of ample parking space

Basic attributes $=31.886+0.93 \times_{1}+0.91 \times_{2}+0.90 \times_{3+} 0.663 \times_{4+} 0.663 \times_{5+} 0.663 \times_{6+} 0.663 \times_{7} \ldots(4)$

Physical attributes $=\mathrm{X}_{8}+\mathrm{X}_{9}+\mathrm{X}_{10}$

$\mathrm{X}_{8}=$ Large room space

$\mathrm{X}_{9}=$ Physical appearance of the hotel/guest house

$\mathrm{X}_{10}=$ Laundry services

Physical attributes $=16.882+0.610 \times{ }_{8+} 0.605 \times{ }_{9+} 0.605 \times 10$

Environmental attributes $=\mathrm{X}_{11}+\mathrm{X}_{12}+\mathrm{X}_{13}$

$\mathrm{X}_{11}=$ Serenity of the neighborhood

$\mathrm{X}_{12}=$ Availability of a bar/café 
$\mathrm{X}_{13}=$ Availability of LCD TV in the room

Environmental attributes $=9.311+0.83 \times_{11}+0.79 \times_{12}+0.79 \times_{13}$

Complementary attributes $=\mathrm{X}_{14}+\mathrm{X}_{1}$

$\mathrm{X}_{14}=$ Variety in cuisine

$\mathrm{X}_{15}=$ Availability of internet services

Complementary attributes $=6.839+0.78 \times_{14}+0.76 \times{ }_{15}$

\section{Recommendation and Conclusion}

The hedonic price model quantified the effect of each of the significant variables on the room rates. This allows prospective investors make economic estimates of the impact of decisions concerning the variables. This is important as some of these variables are things that should be taken into consideration at the inception of the project to avoid unnecessary spending on modification projects in the later life of the investment. The results also proof useful to hotel managers as it shows the essential needs of the hotel/ guest houses. It is a tool for cost effectiveness and investment sustainability

Unlike the results of similar studies by Chen et al. (2010) carried out in Taipei, this study shows that four attributes are most important to lodgers. These are regular water supply, constant power supply, closeness to the city centre and good room service. The difference in results is a reflection of the difference in socio-economic factors of the different regions. While Nigeria is still struggling with the development of sustainable infrastructure, the Chinese are on the level of worrying about more intimate issues.

The importance of prime locations in investment citing has been buttressed in this study. With a RII of 0.9 , lodgers would give up almost every other thing to be close to the city centre. This simply shows that revenue generated from a hotel investment in a choice location is likely to cover the high cost of acquiring the investment. The analysis also shows that a high level importance is attached to the provision of regular power and water supply by customers. The current erratic state of power supply in the nation may however be a deterrent to this. Investors and managers are therefore encouraged to look into alternative means of power supply like the use of solar panels.

Most importantly, it is necessary that investors and managers take into consideration attributes of hotels/guest houses in line with customers' value hierarchy when taking investment decisions to realize optimum return on their investment. They must also be sensitive to changes in customer tastes to enhance investment sustainability

\section{References}

Chen, C.-F., \& Rothschild, R. (2010). An application of hedonic pricing analysis to the case of hotel rooms in Tapei. Tourism Economics.

Coenders, G., Espinet, J. M., \& Sae, M. (2001). Predicting random level and seasonality of hotel prices. $A$ structural equation growth curve approach. 1-21.

Cooper C., Fletcher J., Gilbert D. and Wanhill S. (1996). Tourism: Principles and Practice, Longman, London

DeRoos, J. \& Rushmore, S. (2006). Hotel valuation techniques.

Espinet, J. M., Saez, M., Coenders, G., \& Fluvia, M. (2003). Effects on the prices of attributes of holiday hotels: a hedonic prices approach. Tourism Economics , 1-13.

Fanning S.F. (2005). Market Analysis for Real Estate, Appraisal Institute, Chicago

Hinterhuber, A. (2008). Customer value-based pricing strategies: why companies resist. Journal of Business Strategy, 125-134.

Kone D.L. (2006). Land Development $10^{\text {th }}$ ed., Buildersbooks.com, Washington D.C. USA

Lewis, C., \& Shoemaker, S. (1997). Price Sensitivity Measurment A tool for the hospitality industry. Cornell Hotel and Restaurant Administration quarterly, 44-54.

Pearce, P. L. (1995). From culture shock and culture arrogance to culture exchange: Ideas towards sustainable socio-cultural tourism. Journal of sustainable tourism, 143 - 154.

Rosen, S. (1974). Hedonic Prices and Implicit Markets: Product Differentiation in Pure Competition. The Journal of Political Economy, 34-55.

Scott B. (2008). Hotels in the edited book Valuation: Principles into Practice $6^{\text {th }}$ ed. Pg 463 EG books London.

Shilling D.J. (2002). Real Estate $13^{\text {th }}$ ed. Thomson Learning, Ohio, USA

Shoemaker, S. (2003). The future of pricing in services. Journal of Revenue and Pricing Management, 271-279.

Varini, K., Englemann, R., Claessen, B., \& Schleusener, M. (2003). Evaluation of the price-value perception of customers in Swiss hotels. Journal of Revenue and Pricing Management, 47-60.

White, P. J. (2000). Site and situation determinanats of hotel room rates. Arizona. 
Table 1. Complete list of attributes considered

\begin{tabular}{|l|l|}
\hline 1. & Large room space \\
2. & Location is close to the city center \\
3. & Location is close to the airport \\
4. & Serenity of the neighborhood \\
5. & Physical appearance of the hotel/guest house \\
6. & Availability of LCD TV in the room \\
7. & Availability of a business center \\
8. & Availability of a bar/café \\
9. & Availability of interest services \\
10. & Availability of shuttle services \\
11. & Availability of conference facilities \\
12. & Availability of swimming pool \\
13. & Availability of fitness center/gymnasium \\
14. & Variety in cuisine \\
15. & Availability of a club \\
16. & Variety of satellite TV stations \\
17. & Good room service \\
18. & Hotel/guest house is affiliated to a chain of hotels \\
19. & Laundry services \\
20. & Constant power supply \\
21. & Availability of ample parking space \\
22. & Regular water supply \\
\hline
\end{tabular}

Table 2. Reasons Respondents Lodge in Hotels/Guest Houses

\begin{tabular}{lcc}
\hline Category & Frequency & Percentage \\
\hline Business & 88 & 57.1 \\
Leisure & 32 & 20.8 \\
Tourism & 18 & 11.7 \\
Others & 16 & 10.4 \\
\hline Total & $\mathbf{1 5 4}$ & $\mathbf{1 0 0 . 0}$ \\
\hline
\end{tabular}

Source: Field Survey, 2010

Table 3. On the Average, How Often do you Lodge in Hotels/Guest-Houses?

\begin{tabular}{lcc}
\hline Category & Frequency & Percentage \\
\hline Once a week & 56 & 36.4 \\
Once in two weeks & 30 & 19.5 \\
Once monthly & 20 & 13.0 \\
Once in three months & 34 & 22.1 \\
Once yearly & 8 & 5.2 \\
Less than one a year & 6 & 3.9 \\
\hline Total & $\mathbf{1 5 4}$ & $\mathbf{1 0 0 . 0}$ \\
\hline
\end{tabular}

Source: Field Survey, 2010

Table 4. On the Average, How Often do you Lodge in this Particular Hotel?

\begin{tabular}{lcc}
\hline Category & Frequency & Percentage \\
\hline Once a week & 50 & 32.5 \\
Once in two weeks & 32 & 20.8 \\
Once monthly & 22 & 14.3 \\
Once in three months & 30 & 19.5 \\
Once yearly & 8 & 5.2 \\
Less than one a year & 12 & 7.8 \\
\hline Total & $\mathbf{1 5 4}$ & $\mathbf{1 0 0 . 0}$ \\
\hline
\end{tabular}

Source: Field Survey, 2010 
Table 5. Rate Per Night for this Accommodation

\begin{tabular}{lcc}
\hline Category & Frequency & Percentage \\
\hline N1,000-N10,000 & 50 & 32.5 \\
N11,000-N20,000 & 44 & 28.6 \\
N21,000-N30,000 & 20 & 13.0 \\
N31,000-N40,000 & 8 & 5.2 \\
N40,000 and above & 32 & 20.8 \\
\hline Total & $\mathbf{1 5 4}$ & $\mathbf{1 0 0 . 0}$ \\
\hline
\end{tabular}

Source: Field Survey, 2010

Table 6. Ranking of the Facilities Available to Respondents Hotel/Guest House

\begin{tabular}{|l|l|l|}
\hline Facilities Available in Hotel/Guest House & RII & Rank \\
\hline Regular water supply & .93 & 1 \\
\hline Constant power supply & .91 & 2 \\
\hline Location is close to the city centre & .90 & 3 \\
\hline Good room service & .90 & 4 \\
\hline Location is close to the airport & .89 & 5 \\
\hline Variety of satellite TV stations & .87 & 6 \\
\hline Availability of ample parking space & .87 & 7 \\
\hline Large room space & .86 & 8 \\
\hline Physical appearance of the hotel/guest house & .84 & 9 \\
\hline Laundry services & .84 & 10 \\
\hline Serenity of the neighborhood & .83 & 11 \\
\hline Availability of a bar/café & .79 & 12 \\
\hline Availability of LCD TV in the room & .79 & 13 \\
\hline Variety in cuisine & .78 & 14 \\
\hline Availability of internet services & .76 & 15 \\
\hline Availability of shuttle services & .75 & 16 \\
\hline Hotel/guest house is affiliated to a chain of hotels & .73 & 17 \\
\hline Availability of swimming pool & .71 & 18 \\
\hline Availability of fitness centre/gymnasium & .71 & 19 \\
\hline Availability of a business centre & .71 & 20 \\
\hline Availability of conference facilities & .69 & 21 \\
\hline Availability of a club & .64 & 22 \\
\hline Source: & & \\
\hline
\end{tabular}

\section{Source: Field Survey, 2010}

Table 7. Eigen Values Establishing Significant Values

Total Variance Explained

\begin{tabular}{|c|c|c|c|c|c|c|c|c|c|}
\hline \multirow[b]{2}{*}{ Component } & \multicolumn{3}{|c|}{ Initial Eigenvalues } & \multicolumn{3}{|c|}{ Extraction Sums of Squared Loadings } & \multicolumn{3}{|c|}{ Rotation Sums of Squared Loadings } \\
\hline & Total & $\%$ of Variance & Cumulative \% & Total & $\%$ of Variance & Cumulative \% & Total & $\%$ of Variance & Cumulative \% \\
\hline 1 & 4.783 & 31.886 & 31.886 & 4.783 & 31.886 & 31.886 & 3.251 & 21.676 & 21.676 \\
\hline 2 & 2.532 & 16.882 & 48.768 & 2.532 & 16.882 & 48.768 & 3.129 & 20.859 & 42.536 \\
\hline 3 & 1.397 & 9.311 & 58.079 & 1.397 & 9.311 & 58.079 & 2.156 & 14.372 & 56.907 \\
\hline 4 & 1.026 & 6.839 & 64.918 & 1.026 & 6.839 & 64.918 & 1.202 & 8.011 & 64.918 \\
\hline 5 & .947 & 6.314 & 71.232 & & & & & & \\
\hline 6 & .795 & 5.300 & 76.532 & & & & & & \\
\hline 7 & .718 & 4.784 & 81.317 & & & & & & \\
\hline 8 & .616 & 4.105 & 85.422 & & & & & & \\
\hline 9 & .543 & 3.619 & 89.041 & & & & & & \\
\hline 10 & .436 & 2.909 & 91.951 & & & & & & \\
\hline 11 & .340 & 2.265 & 94.216 & & & & & & \\
\hline 12 & .319 & 2.129 & 96.345 & & & & & & \\
\hline 13 & .244 & 1.627 & 97.973 & & & & & & \\
\hline 14 & . 162 & 1.080 & 99.052 & & & & & & \\
\hline 15 & . 142 & .948 & 100.000 & & & & & & \\
\hline
\end{tabular}

Extraction Method: Principal Component Analysis.

a. Only cases for which Considering the above ratings, are you satisfied paying the stipulated room rates? = Yes are used in the analysis phase. 
Table 8. Factor Analysis of attributes

\begin{tabular}{|c|c|c|c|c|}
\hline Components & Eigen value & e \%age of variance & Facilities Available & RII \\
\hline \multirow[t]{7}{*}{1} & 4.783 & 31.886 & Regular water supply & 0.93 \\
\hline & & & Constant power supply & 0.91 \\
\hline & & & Closeness to city centre & 0.90 \\
\hline & & & Good room service & 0.90 \\
\hline & & & Closeness to the airport & 0.89 \\
\hline & & & Variety of TV satellite Station & 0.87 \\
\hline & & & Availability of ample parking space & 0.87 \\
\hline \multirow[t]{3}{*}{2} & 2.532 & 16.882 & Large room space & 0.86 \\
\hline & & & Physical appearance of hotel/guest house & 0.84 \\
\hline & & & Laundry service & 0.84 \\
\hline \multirow[t]{3}{*}{3} & 1.397 & 9.311 & Serenity of the neighborhood & 0.83 \\
\hline & & & Availability of a bar/café & 0.79 \\
\hline & & & Availability of LCD/TV in the room & 0.79 \\
\hline \multirow[t]{2}{*}{4} & 1.026 & 6.839 & Variety in cuisine & 0.78 \\
\hline & & & Availability of internet service & 0.76 \\
\hline
\end{tabular}

Table 9. Regression Table

\begin{tabular}{llllccc}
\hline & Model & Sum of Square & df & Mean Square & F & Sig. \\
\hline 1 & Regression & 129.527 & 4 & 32.382 & 24.088 & 0.00 \\
Residual & 163.348 & 123 & 1.344 & & \\
Total & 294.875 & & & &
\end{tabular}

a. Predictor: (Constant), Com 1 Basic Attributes, Com 2 Physical Attributes, Com 3 Environmental Attributes, Com 4 Complementary Attributes

b. Dependent Variable; Rate Per night for Accomodation

$R=.663, R^{2}=.439(43.9 \%), \quad$ ADJ $R^{2}=.421(42.1 \%) ; \quad T$-value $=13.817^{* *}$,

Durbin Waston $=2.334$; Significance at 0.000, Constant $=1.513$, Dv $=$ SEPV $=0.232$, SE $=0.65$

Table 10 . Coefficients ${ }^{\mathrm{a}}$

\begin{tabular}{|c|c|c|c|c|c|}
\hline \multirow[t]{2}{*}{ Model } & \multicolumn{2}{|c|}{$\begin{array}{l}\text { Unstandardized } \\
\text { Coefficients }\end{array}$} & \multirow{2}{*}{$\begin{array}{c}\begin{array}{l}\text { Standardized } \\
\text { Coefficients }\end{array} \\
\text { Beta } \\
\end{array}$} & \multirow[t]{2}{*}{$\mathrm{T}$} & \multirow[t]{2}{*}{ Sig. } \\
\hline & $\beta$ & Std.Error & & & \\
\hline (Constant & 5.140 & & & 13.817 & .000 \\
\hline Com 1 Basic Attributes & -.357 & .078 & -.497 & 4.582 & .000 \\
\hline Com 2 Physical Attributes & -.130 & .049 & -.305 & 2.660 & .009 \\
\hline Com3 Environmental Attributes & -.237 & .083 & -.259 & 2.854 & .005 \\
\hline Com4 Complementary Attributes & -.168 & .069 & -.231 & 2.319 & .012 \\
\hline
\end{tabular}

a. Dependent variable: Rate Per night for Accommodation

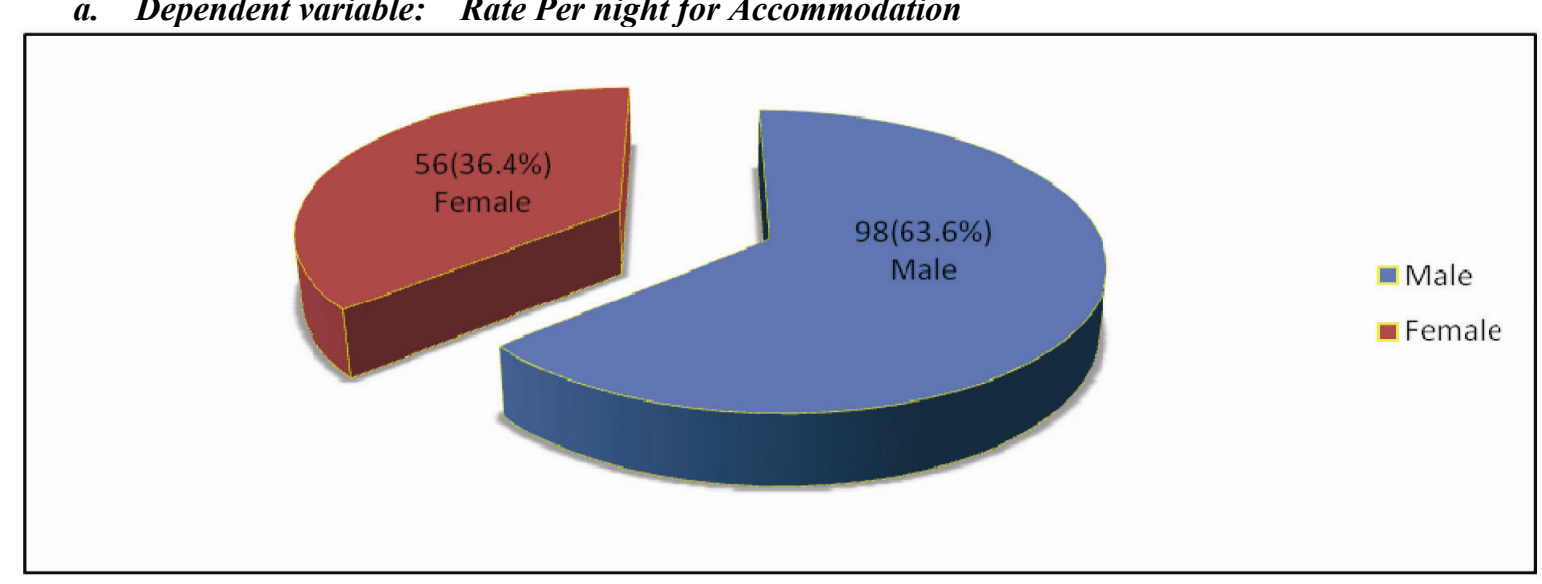

Source: Field Survey, 2010.

Figure 1. Distribution of the Respondents by Sex 


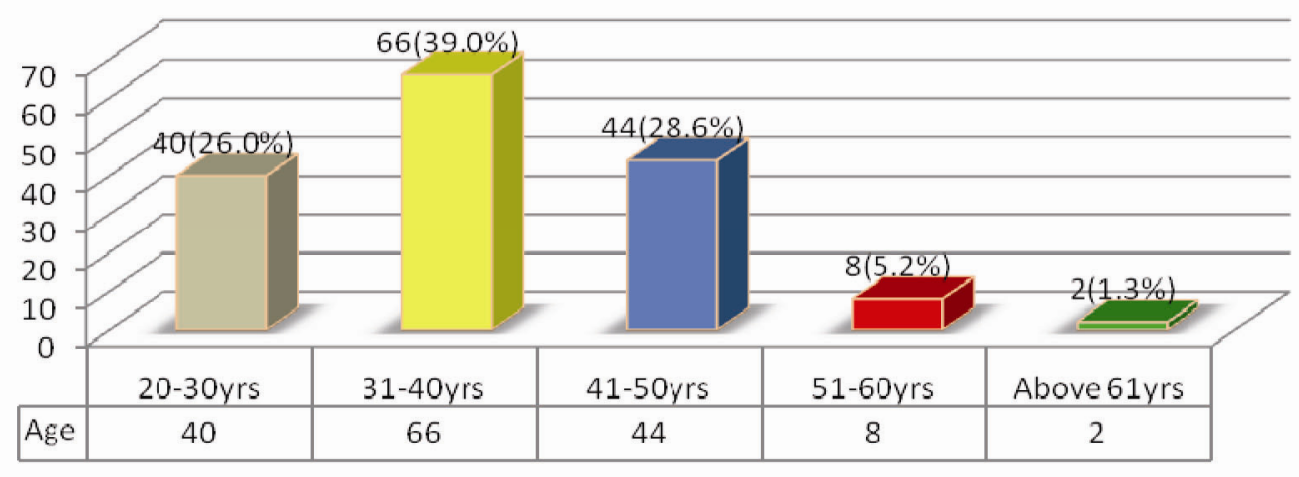

Source: Field Survey, 2010.

Figure 2. Distributions of the Respondents by Age

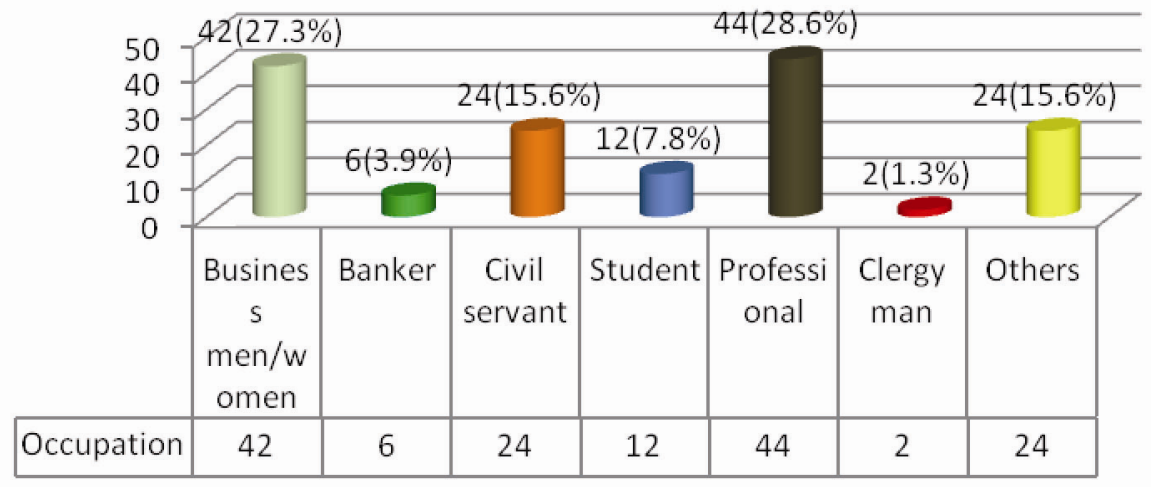

Figure 3. Distributions of the Respondents by Occupational Status

Source: Field Survey, 2010.

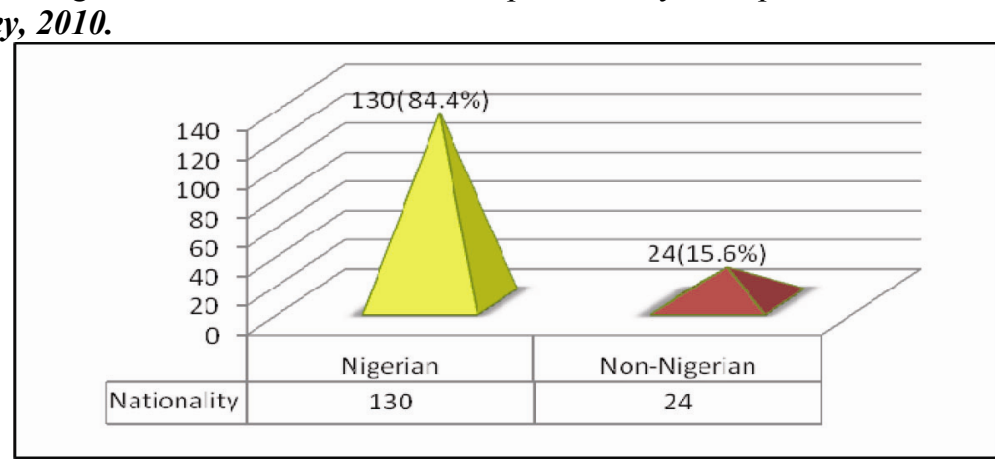

Source: Field Survey, 2010.

Figure 4. Nationality of respondents 